\title{
LEGAL PROTECTION AGAINST THE FAILURE TO COMPENSATE ON INTERNATIONAL INVESTMENT DISPUTE
}

\author{
Vunieta; Walida Ahsana Haque \\ Faculty of Law, Universitas Airlangga \\ Email: vunietavv@gmail.com, walidahaque@gmail.com
}

\begin{abstract}
A dispute between two or more countries involved in a foreign investment may arises from investment agreement agreed upon by the parties. If one of the parties breaches the agreement, the parties will automatically agree to resolve the dispute to the agreed arbitration forum based on the dispute settlement clause on the agreement, those forum such as the ICSID arbitration. Therefore, the existence of dispute settlement clause on an investment agreement (Bilateral Investment Treaty) is very necessary. The result of the above-mentioned arbitration proceeding is a binding and final decision for the parties. An arbitral award, should contain relief or compensation set by the arbitrator as the result of the proceeding. The reliefs are given as orders to indemnify the damages obtained by Claimant. Issues arises when Respondent has been proven to have done detrimental damage to the Claimant yet Respondent deliberately neglected his/her obligation to compensate Claimant accordingly based on the relief/ compensation specified in the award. The non-compliance of the Respondent to fulfill the compensation obligation is due to the fact that the party habitually assume that the arbitration award does not have the legal force equivalent to the decision of general court, even though the nature of the award is final and binding. Thus the interests and rights of the Applicant who has been declared entitled to compensation based on the arbitration award must be protected so that their rights can be fulfilled according to the law.
\end{abstract}

Key Words: Legal Protection; Arbitration; ICSID; Compensation; Award.

\section{INTRODUCTION}

An agreement has been established when there is a consent between one party to another which is either poured down in writing or in verbal. As a subject of the law, both individual undertaker and a State has the right to establish a contract as the consent between them has been raised. The agreement will have the nature of binding as it is regulated under the Civil Code, those according to the principle of the Pacta Sunt Servanda, which is contained in Article 1338 of the Civil Code. The principle of Pacta Sunt Servanda means the agreement itself will bind the parties stated on it, as the law which the parties must comply with. Because of the binding nature of

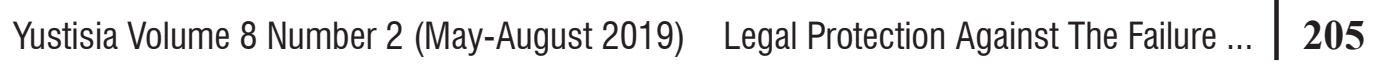

(C)2019; This is an Open Acces Research distributed under the term of the Creative Commons Attribution Licencee (https://Creativecommons.org/licences/by/4.0), which permits unrestricted use, distribution, and reproduction in any medium, provided the original works is properly cited. 
the agreement, it is very necessary to establish a dispute settlement clause in case of any breach of contract by the parties or other dispute that causes the contract to be ineffective. In those particular dispute settlement clause, the forum of arbitration is a very common alternative between business undertakers as it's award has the nature of final and binding (Mosgan Situmorang, 2017:310).

International Investment Arbitration's forum, in this particular case is the ICSID Arbitration, covers sector in public law and private law, it covers the public sector because one party can be a host-state, which has a public nature as it is the highest organization among the people. It covers the sector of private law because the parties act as entities that bind themselves to each other through legal actions that create rights and obligations for both parties. Article 25 (1) of the International Center for Settlement Investment Dispute ("hereinafter referred to as ICSID") confirms that legal issues arising from the parties of a Bilateral Investment Treaty (BIT) are the jurisdiction of the ICSID arbitration (Article 26 (1) of ICSID Convention). However, the settlement of disputes between the parties can be done according to the agreed forum and according to the agreed choice of law stated in the agreement, which means that an agreed forum and agreed choice of law must be regulated in the agreement. If it is firmly stated on the agreement that ICSID Arbitration will be the chosen forum to any dispute arising from those before-mentioned agreement, then the ICSID Arbitration forum will have the absolute jurisdiction in resolving the dispute. The breach of the agreement occurs between host-state and investors are the object of disputes within the scope of ICSID Arbitration, but it has to be expressly stated in the agreement that all kinds of disputes arising from the agreement will be resolved through the arbitration proceeding in the ICSID arbitration forum. Another requirement for the proceeding is that both parties, the host-state and home-state are members of the ICSID Convention which have certain jurisdictional limits (Lydia Kaunang,, 2017:106).

Indonesia has ratified the ICSID Convention, which has been set out in the form of a law, namely Law Number 5 year 1968 on The Settlement of Disputes Between State and Foreign Citizens Regarding on Investment. Article 1 of Law Number 5 year 1968 states that Indonesia has recognized the Convention on the Settlement of Investment Dispute Between States and Nationals of Other States. But even though the Government of the Republic of Indonesia has ratified the ICSID Convention, it does not mean that automatically any dispute between foreign investors and the Government of Indonesia must be resolved by the ICSID arbitration board. In the event that the state does not comply with the arbitration award, the investor can seek enforcement in a National Court and place enforcement of commercial assets in its jurisdiction. In executing the ICSID arbitration award, each contracting state is required to comply with the decision that has been included in the arbitration award

206 Yustisia Volume 8 Number 2 (May-August 2019) Legal Protection Against The Failure ... 
as a final decision. This ICSID arbitration award is only binding the parties of the dispute and it requires Respondent to obey the arbitration award.

Article 65 of Law Number 30 of 1999 on The Alternative Dispute Resolution states that only Central Jakarta District Court has the authority recognize and implement international arbitration award. Thus in carrying out the execution of the arbitral award or carrying out compensation for disputes covering the law jurisdiction of the Republic of Indonesia, it must firstly obtain the decision of recognization of the Central Jakarta District Court. In practice, however, many of the arbitral awards are not carried out by the Respondent with various objections, including the objection on the form of compensation handed down. Failure to compensate can also occur when the National Court rejects an implementation of the arbitration award, because it is deemed to exceed the authority and intervene in the implementation of the judicial process in that state. In fact, the National Court can intervene at any time in the right to hear the arbitration process. As in the case of AMCO ASIA v. THE REPUBLIC OF INDONESIA which signifies that the arbitration award issued by the international arbitration judge has exceeded the authority established by the Convention and has intervened in the implementation of the judicial process in Indonesia. In connection with the case of AMCO ASIA v. THE REPUBLIC INDONESIA, it needs to be explained that an Appeal is not recognized in international arbitration award, in other words, Respondent will not be able to submit an appeal against the arbitration award, but there are several choices of procedures that can be carried out against arbitration award in case there are some revisions that is necessary to be made. The procedures is regulated under Article 49 to Article 54 ICSID CONVENTION, which according to Convention, the form of the procedures are Correction, Interpretation, Revision, and Annulment. The forms of the procedure may hamper the implementation of an arbitration award where compensation has been determined.

Another obstacle on the implementation of the arbitral award is when the Respondent does not have the intention to voluntarily fulfill its obligation to pay the compensation specified in the award, thus the Respondent does not comply with the New York Convention. If the payment of compensation is not carried out by the Respondent accordingly, there will be no legal justice for Claimant who has been entitled to the outcome of the execution. It becomes important for the author to discuss the legal procedures that can be done by the entitled party when the party required to fulfill the compensation refuses to do so. According to this introduction, this article will analysis the granting of compensation by the International Investment Arbitration Forum as the form of legal protection for the disputing parties, and How the leegal protection for lack of voluntary compliance by Respondent is.

\begin{tabular}{ll|l}
\hline Yustisia Volume 8 Number 2 (May-August 2019) $\quad$ Legal Protection Against The Failure ... & $\mathbf{2 0 7}$
\end{tabular} 


\section{RESEARCH METHODS}

The type of this research uses normative legal research, a legal research that is conducted based on law and regulation and library material, which is known as secondary material. Related with this type of research, the approach used in this paper are legal approach and historical approach. these approach are done by reviewing the acts and regulations that related to the problem that is being discussed in this research

\section{DISCUSSION AND RESEARCH RESULT}

\section{A. Compensation in International Investment Arbitration}

The jurisdiction of the ICSID arbitration forum is regulated under Article 25 of the 1965 Washington Convention, which stipulates the elements of what is called as ICSID arbitration forum including: (1) the object of dispute must be related to investment; (2) involving the ratifying States and citizens of the ratifying States; (3) have an agreement in the written form; and (4) can not be withdrawn unilaterally (Prita Amalia dan Garry Gumelar Pratama, 2018:7). When parties on international investment agreement agrees on dispute settlement through ICSID arbitration, it gives the parties the obligation to voluntarily obey the rules written in the ICSID convention. If there is a failure in carrying out the implementation of the Convention, there will be compensation given to the entitled party.

This compensation is stated inside of a Tribunal Award from the Panel of Judges in ICSID arbitration after a dispute between the contracting states arose and proceed. If it is elaborated from the beginning of the arbitration process, before the parties begin the trial, the parties will first determine the choice of law, which will later be used in the trial. Choice of law is one of the mandatory requirements that must be included in contracts, especially Bilateral Investment Treaty (BIT), given that the parties adhere to different laws (Indra Tri Kurniawan, 2012:23). Choice of law in the investment agreement clause is needed to avoid conflict of law between the disputing parties. The principle of choice of law here will also apply to the position of compensation to be carried out by the Respondent, whether the compensation is carried out in accordance with the law of the host state or the law of the home state.

The ICSID Convention itself does not specifically regulate the form of relief or compensation for an investment dispute, whether in the form of how and to what extent the compensation will be applied, therefore, there is a lack of regulations regarding the form of compensation in the international and national scope. In practice, determining the form of compensation will be based on legal considerations of the arbitrators and through several calculations of

208 Yustisia Volume 8 Number 2 (May-August 2019) Legal Protection Against The Failure ... 
the chosen methods, one of which is the DCF (Discounted Cash Flow) method. Compensation which results from an ICSID arbitration award provides the form of compensation obligation for losses incurred. The ICSID arbitration award is final and binding for the parties to the dispute and there is no appeal against the ICSID arbitration award. The most common forms of compensation in the scope of compensation applied in the ICSID arbitration forum are pecuniary compensation and/or non-pecuniary compensation.

\section{Pecuniary Compensation}

Also recognize as monetary compensation, pecuniary compensation is a form of compensation that emphasizes compensation in the form of money. This type of compensation is given to the Claimant so that Respondent is obliged to pay compensation in the form of money. Pecuniary compensation has been recognized in ICSID Convention Article 54 (1). The Article states that the contracting state is obliged to carry out its pecuniary obligations, i.e. compensation in the form of money, which is stated in the arbitration award. Regarding on how the execution of pecuniary obligations will be commenced depends on the sovereignty of a State who receives this compensation. However, this implementation is mandatory because the position of the ICSID arbitration award has the nature of final and binding to the parties of the dispute.

\section{Non-Pecuniary Compensation}

In the concept of non-pecuniary compensation, there are three scopes of compensation that will be given, namely in the form of provisional measures, asset restitution, and orders to take certain actions. If in the case of provisional measures, it means that investors may need urgent action that must be taken to prevent adverse measures from the country awaiting resolution of the dispute (Sylvia Noury, 2009:9). So here investors need an action to avoid actions that will be more detrimental to the opposing party. Actions in provisional measures can only be carried out if needed and deemed urgent, with the aim of providing the effectiveness of the course of arbitration and avoiding other violations in a dispute.

The existence of compensation as compensation for losses incurred in an arbitral award, can only be used by the Respondent based on the ICSID Convention which states that the award is binding on the parties. However, based on the ICSID Convention, it is not specifically stipulated what form of compensation will be given. In Article 54 (1), it is stated that the parties are to carry out the pecuniary obligations specified in the investment arbitration award. The statement is wrong if we conclude that the provisions stating that the ICSID

\begin{tabular}{ll|l}
\hline Yustisia Volume 8 Number 2 (May-August 2019) Legal Protection Against The Failure ... & $\mathbf{2 0 9}$
\end{tabular} 
court may not provide non-pecuniary compensation as ordered for certain actions (Sylvia Noury, 2009:9).

Some arbitral tribunals have asserted their power to provide whatever compensation they deem appropriate and have ordered non-pecuniary compensation, solely or in combination with pecuniary compensation. In choosing the compensation that will be demanded by the opposing party, this will relate to the right to regulate, as the Indonesian state has sovereignty, especially the right to regulate, then the implementation of non-pecuniary compensation follows the applicable law in Indonesia.

In determining the amount of compensation, ICSID arbitration uses several methods as a reference for providing compensation. Where in general ICSID arbitration more often provides compensation in the form of compensation by assessing the value of investor assets. Some of these methods include using traditional or other calculation methods (Sylvia Noury, 2009:417). These traditional calculation methods are the methods that have been regulated in the World Bank Guidelines. In this type of method there are several types of stages that are often used, among others in the form of liquidation values; replacement value; book value; discounted cash flow value (DCF). According to the Development Committee in collaboration with the World Bank Guidelines, it is stated that compensation using this method is not suitable for speculative or indeterminate losses, or for alleged profits that cannot be obtained legally based on the host state's laws and regulations. Other types of calculation methods use several approaches, some of which have been implemented in some ICSID cases. For example, the comparable transaction approach [11] and the option approach.

\section{B. Implementation of Foreign Arbitration Compensation in Indonesian Law}

The difference in implementation of court decisions and an award resulting from the ICSID Arbitration is very pronounced. That is because those who have authority or power comes from state power in the field of judiciary, while arbitration does not come from a state power, but it comes from an agreement made by the parties (Mosgan Situmorang, 2017:313). Arbitration awards have a voluntary nature, meaning that those who lose the case are expected in good faith to enforce the award voluntarily. However, if an arbitration award is not carried out accordingly, a request for assistance from the court can be made at the place where the Respondent is located.

\section{Execution of Compensation in Indonesian National Law}

Compensation or what is known as compensation in Indonesian national law, is equivalent to the concept of compensation applicable in Burgerlijk

210 Yustisia Volume 8 Number 2 (May-August 2019) Legal Protection Against The Failure ... 
Wetboek (BW) as in Article 1246 BW.

According to Purwahid Patrik, there are two elements of loss, including:

a) The actual losses suffered (Damnum emergens) include costs and losses

b) Benefits not obtained (Lucrum Cessans) include interest (M. Tjoanda, 2010:45).

However, the existence of compensation for interests that cannot be valued in money, such as in the form of non-pecuniary compensation in arbitration, has been recognized in Article 1601 of Burgerlijk Wetboek. what was meant is that, It is not depends on the nature of the interests of the Claimant, but whether the Claimant's rights can be recovered by paying compensation in the form of money. But apart from the aforementioned matters, non-economic compensation is usually better to be implemented rather than a sum of money as a means of rehabilitation, as long as the amount of compensation was "effective" in accordance with the calculation that allows the achievement of recovery results that are close to the original state.

In the case of the implementation of compensation to be carried out by the Respondent, in Indonesian national law, it is first required for the existence of recognition of the arbitration award to the Court that has been regulated in Law Number 30 of 1999 on The Arbitration and Alternative Dispute Resolution. The recognition and enforcement of arbitration awards rests with the authority of the Central Jakarta District Court. Based on these provisions, it can be said that the one who holds that authority is only the Central Jakarta District Court. Or in other words, the implementation (enforcement)of the award, in addition to of course handling the problem of recognition of foreign arbitration decisions in Indonesia, have been delegated centrally and become the full authority of the Central Jakarta District Court (Nurhadi, 2005:46). This is the same as stated by Z. Asikin Kusumah Atmadja, that given the importance and extent of the problems that arise with the substance of the regulations in the field of arbitration, then they deemed necessary to resolve this issue is the Central Jakarta District Court (Sudargo Gautama, 1999:132).

Determining whether an international arbitration award is accepted or rejected in Indonesian territory will be more difficult. The host-state has the right to either accept and recognize or reject the award and that is due to the State Sovereignty. If the form of compensation does not contradict the sovereignty of their country, the award will be accepted and recognized. However, if the compensation violates the sovereignty of the Host-State, it is possible that the award will be rejected.

\begin{tabular}{ll|l}
\hline Yustisia Volume 8 Number 2 (May-August 2019) Legal Protection Against The Failure ... & $\mathbf{2 1 1}$
\end{tabular} 


\section{The Consequences of the Law for Refusing Compensation in Indonesia}

The form or type of sanctions from the international community are also not certainly regulated. Because this is related to international law, one of which is the source of international law, customary. Imposing sanctions against rejection of compensation by Indonesia can be said to be a habit in the international realm, because it is deemed not to comply with the position of an arbitration award that is final and binding.

For example in the case of Amco Asia v. Indonesia, where the Indonesian government submitted an application for cancellation of the arbitration award which had been decided by ICSID. With regard to this cancellation request, the Ad Hoc Committee later canceled part of the decision. Although the Indonesian government has tried to request the cancellation of this ruling as an act of denial of compensation deemed harmful, in the case it was stated that the Ad Hoc Committee's court still stated that the Indonesian police and military officers had violated the law. If in the case of an application for rejection of an ICSID arbitration award is accepted, then the legal consequence that may occur is the alienation of the state's position within the scope of international law. This is possible because it considers that the country has ignored the position of ICSID decisions that are international in nature and must be obeyed by the disputing parties.

In the event of a refusal of compensation, this will relate to the lex mercatoria principle as a general principle in international arbitration law. In general, lex mercatoria will apply if there is a legal vacuum regarding the regulation (Meria Utama, 2013:13). For example, in the condition that Indonesia does not have the arrangements as needed to adjudicate, the court will implement the lex mercatoria principle in a balanced manner. As was the case with the ICSID arbitration award in the case of Amco Asia, at Amco Asia's request, the parties basically did not have agreement on the rules that would be used in resolving their dispute. Therefore, ICSID finally applied Indonesian law in resolving disputes. This is based on contracts made by the parties and international law (Suleman Batubara and Orinton Purba, 2013:55) . ICSID also states that in view of the disputed parties, international law can be applied to it. [18] So in this case the implementation of lex mercatoria in determining the application of the law that will be used in Amco Asia dispute resolution. 


\section{Legal Protection against State's lack of voluntary compliance on paying Compensation.}

The ICSID arbitration award will bind and effective for the parties in dispute, thus include the Claimant, who is the party who filed the claim, and the respondent as the party is against the Claimant. If the claim is granted by the arbitration judge, then the decision of the Judge (Tribunal) of the arbitration must be carried out by the Respondent in the form of either of Pecuniary Compensation or NonPecuniary Compensation, which in its implementation will require a long time and a long process, particularly in Indonesia considering the implementation of the ICSID Award in Indonesia requires recognition from the Central Jakarta District Court before it can be carried out.

The implementation of an ICSID arbitration award depends on sovereignty the state. If the form of compensation does not contradict the law and regulation of the sovereign state, the recognition of the international arbitration award can be requested before the National/District Court in that state. However on the contrary, if the form of the compensation specified on the award contradicts to the sovereignty of the Host-State, it is possible that the National/District Court will reject the request of recognition of the arbitration award. This rejection of the implementation of compensation due to immunity in the sovereignty of the State could harm the rights of Claimant in receiving a fair amount of compensation, which will be detrimental to the Claimant whose rights have been granted by Arbitral Tribunal. There should be a law that requires Respondents who are obliged to pay compensation based on the award to fulfill their obligations, so that the values of justice can be carried out properly in the international arbitration process and those who are entitled to compensation can be fulfilled.

Article II of the New York Convention on the Recognition and Enforcement of Foreign Arbitral Awards (New York, 1958) stipulates that every country who has signed or ratified this convention, such as Indonesia who has ratified the New York Convention on October 7th, 1981, must recognize that a foreign arbitral award has a binding legal force and must implement the award in accordance with the applicable laws in the country where the award must be implemented, and the District Court's Decision on recognition and implementation of the arbitral award must contain the exact same amount of compensation specified in the International Arbitration Award, thus the implementation of the arbitration award after it is being recognized has the same consequences as the decision issued by the Arbitral Tribunal.

Article I paragraph 1 of the New York Convention stated that this Convention shall apply to the recognition and enforcement of arbitral awards made in the territory of a State other than the State where the recognition and enforcement of

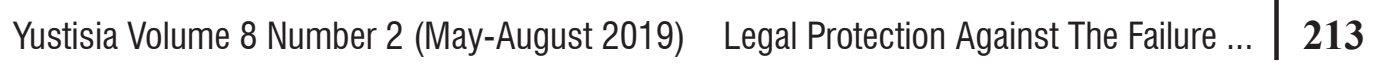


such awards are sought, and arising out of differences between persons, whether physical or legal. It shall also apply to arbitral awards not considered as domestic awards in the State where their recognition and enforcement are sought. When a State agrees to be bound by the Convention, a State can declare that it will apply the Convention (a) in connection with an arbitral award made in the territory of another Party, and (b) only for legal relations that are considered "commercial" under the national law of the State.

An issue will arise is when the host-state, who is acting as a Respondent in international arbitration particularly in ICSID, does not fulfill its obligation to pay compensation to the foreign investors who is acting as the Claimant. The state's negligence to fulfill the obligation to pay compensation will give rise to another legal consequences for the state as the state can be charged with separate claim to fulfill the obligations stated in the ICSID Decision. This obligation in international arbitration is known as the State Responsibility For Non-Enforcement of Arbitral Award. Negligence in fulfilling state's obligations to indemnify may occur due to the refusal of the state to implement the award under the New York Convention, although the Non-enforcement of the award may occur because it is legally or administratively obstructed by the law and procedures in that State (Deyan Draguiev:577).

The responsibility of a state under International Law will be demanded after the act of negligence which is a violation of the state's international obligations, those obligations originated from international legal source instruments, and it binds States as the subject of International Law (Deyan Draguiev:580). Because there is no difference between civil liability and criminal liability in the field of international law, any violation by a State of any international obligation incurs. An example of a regulation in a Bilateral Investment Treaty that requires a state to fulfill its obligations under an ICSID is as exemplified in Article 34 paragraph 8 and paragraph 9 of 2012 U.S. Bilateral Investment Treaty Model as follows:

"8. If the respondent fails to abide by or comply with a final award, on delivery of a request by the non-disputing Party, a tribunal shall be established under Article 37 [State to State Dispute Settlement]. Without prejudice to other remedies available under applicable rules of international law, the requesting Party may seek in such proceedings:

(a) determination that the failure to abide by or comply with the final award is inconsistent with the obligations of this Treaty; and

(b) a recommendation that the respondent abide by or comply with the final award.

9. A disputing party may seek enforcement of an arbitration award under the ICSID Convention or the New York Convention [or the Inter-

$214 \quad$ Yustisia Volume 8 Number 2 (May-August 2019) Legal Protection Against The Failure ... 
American Convention] regardless of whether proceedings have been taken under paragraph $8 . "$

Likewise, it is regulated under Article 53 paragraph 1 of the ICSID Convention that an arbitration award must be binding on the parties and cannot be appealed against it except for the allowed corrective procedure specified in the Convention. The corrective procedure is regulated under Article 49 to Article 54 of the ICSID Convention, which explains the form of the procedure allowed to be submitted against the award, the forms of those above stated procedures are Correction, Interpretation, Revision, Annulment. In case there is no attempt made against the arbitration award, each party must comply with the provisions stated on the arbitration award to the extent that the provisions are in accordance with other provisions relevant to the ICSID Convention.

According to Article 54 of the ICSID Convention, each Contracting State shall recognize an award rendered pursuant to this Convention as binding and enforce the pecuniary obligations imposed by that award within its territories as if it were a final judgment of a court in that State. A Contracting State with a federal constitution may enforce such an award in or through its federal courts and may provide that such courts shall treat the award as if it were a final judgment of the courts of a constituent state. Moreover, it is regulated under Article 55 of the ICSID Convention, that a country does not necessarily have immunity from the obligation to implement an arbitral award merely based on their national law (waiver to sovereign immunity of state). Sovereign Immunity facilitates "the State and its representatives not to be prosecuted in a foreign court because of a public function." (Bernardo Sepulveda-Amor and Merryl Lawry-White, 2017:49). The ICSID Model Clause 15 provides an example of a decisive statement that can be arranged in a Bilateral Investment Treaty to bind Host-State to fulfill the obligations specified in an arbitration award, as follows:

"The Host State hereby waives any right of sovereign immunity as to it and its property in respect of the enforcement and execution of any award rendered by an Arbitral Tribunal constituted pursuant to this agreement"

However, if the Host-State by any means of enforcement is still unwilling to voluntarily fulfill the compensation obligations as specified in the arbitration award, there are several effective legal procedures that can be done by foreign investors as entitled party:

a. Seek diplomatic protection from the government of the Home-State, for example requesting a submission before the International Court of Justice against the Host-State, such as a Freezing Injunction, an order to freeze

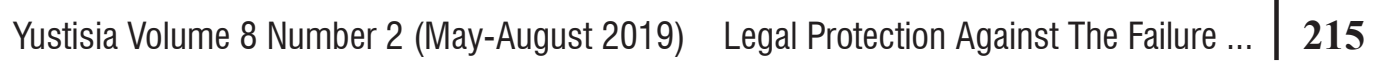


certain assets belonging to the government with the aim of avoiding the removal of assets tied to investment contracts between the Parties. The obstacle of this measure is that this requires an agreement between HomeState and Host-State containing the agreement to submit the case before the International Court of Justice, which is unlikely to be agreed by the HostState;

b. In the event that the host-state submits a cancellation of the arbitration award, the foreign investor as the entitled Party may submit a request before the arbitration judge (Tribunal) to provide a postponement of the implementation of the award until the process of filing the cancellation is complete, with the aim of ensuring the secure the Interest of the Home-State. In case of the cancellation submitted by the Host-State fails, then the foreign investor can directly carry out the execution against the host-state as stipulated in the arbitral award;

c. As a final step, the investor as entitled party may request another form of diplomatic protection from the government of the Home-State. For example, a home-state can initiate an inter-state arbitration process under the protection of an investment agreement or an arbitration process under the International Court of Justice as stipulated in Article 64 of the ICSID Convention. If there is still no resolution obtained, Home-State can take coercive action to provide a deterrent effect to the Host-State, for example reducing or even eliminating the economical benefits previously obtained by the Host-State from international trade relations with the Home-State, as for example in in 2011, the United States voted in the World Bank to cut the extension of the debt period previously granted to Argentine state as a sanction for Argentina's actions for not complying with an International Arbitration Award against The United States.

With the rules under the ICSID Convention and the New York Convention governing the Host-State obligation to comply with the results of the Arbitration Award, and with the existence of legal procedures, as well as diplomatic procedures that can be carried out by Foreign Investors and the Home-State, international investment law has in its capacity provided legal protection for Investors as the winning party in the international arbitration process in the event that the host-state does not comply with its obligation to provide compensation under an international arbitration award. 


\section{CONCLUSION}

Compensation or relief is existed in the substance of an award issued by the International Center of Settlements for International Dispute (ICSID). However, in the ICSID Convention itself, there are no specific provisions governing the form and parameters of compensation, but the provisions contained in the ICSID are specific in regards to the obligations of the party to comply with and implement pecuniary obligations in respect of ICSID arbitral award. The existence of an award does not guarantee the fulfilment of the Claimant's rights, so there are two possibilities, whether it is rejected or accepted by the Host-State, the host-state has the right to either accept and recognize or reject the award and that is due to the State Sovereignty. If the form of compensation does not contradict the sovereignty of their country, the award will be accepted and recognized. However, if the compensation violates the sovereignty of the Host-State, it is possible that the award will be rejected.

If the Respondent refuses or ignores the required compensation under the arbitral award, the Host-State will be exiled within the scope of implementation of the international law. But that is not enough for foreign investors as Claimant because foreign investors are entitled to appropriate compensation payments. There are several procedures that can be carried out by foreign investors to get the fulfillment of their rights. Such procedures include request for diplomatic protection from his own country (Home-State) because only Home-State has the same capacity as HostState to enforce international law to each other, including the award of an arbitration forum. Diplomatic protection can be given in the form of lawsuit assistance to the International Court of Justice, commecing independent inter-state arbitration, or imposing sanctions within the scope of international trade.

\section{BIBLIOGRAPHY:}

\section{Books:}

Batubara, Suleman dan Orinton Purba. (2013). International Arbitration (Arbitrase Internasional). Depok: Raih Asa Sukses.

Dugan, Christopher F. and Don Wallace, (2017). Jr. Investor-State Arbitration, Oxford University Press.

Gautama, Sudargo. (1999). Law on The New Arbitration (Undang-Undang Arbitrase Baru 1999), Bandung: Citra Aditya Bakti.

McLachlan QC, Campbell and Lauren Shore. (2017). International Investment Arbitration: Substantive Principles Second Edition. United Kingdom: Oxford International Arbitration Series.

\footnotetext{
\begin{tabular}{ll|l}
\hline Yustisia Volume 8 Number 2 (May-August 2019) Legal Protection Against The Failure ... & $\mathbf{2 1 7}$
\end{tabular}
} 
Ripinsky, Sergey, and Kevin Williams. (2008). Damages in International Investment Law. London: British Institute of International and Comparative Law.

\section{Journals:}

Amalia, Prita and Garry Gumelar Pratama. (2018). Indonesia dan ICSID: Pengecualian Yuridiksi ICSID Oleh Keputusan Presiden, Majalah Hukum Nasional Nomor 1 Tahun 2018.

Draguiev, Deyan. State Responsibility For Non-Enforcement of Arbitral Awards. World Arbitration \& Mediation Review (WAMR), Volume 8, Number 4

Kaunang, Lydia. (2017). Penyelesaian Sengketa Penanaman Modal Menurut UndangUndang Nomor 25 Tahun 2007, Lex Privatum VolumeV/No.6/Ags/2017.

Kurniawan, Indra Tri. (2012). Arbitrase Internasional Sebagai Pilihan Forum dalam Penyelesaian Sengketa Kontrak Kerjasama Internasional. Skripsi Fakultas Hukum Universitas Airlangga,

Noury, Sylvia. (2009). Remedies against states in investor-state arbitration - more bark than bite?, Freshfields Bruckhaus Deringer: BIICL Annual Conference.

Sepulveda-Amor, Bernardo and Merryl Lawry-White, (2017). State responsibility and the enforcement of arbitral awards, Arbitration International.

Situmorang, Mosgan. (2017). Pelaksanaan Putusan Arbitrase Nasional di Indonesia, Jurnal Penelitian Hukum De Jure, Volume 17, Number 4.

Smutny, Aby Cohen. (2006). Principles Relating to Compensation in The Investment Treaty Context, Investment Treaty Arbitration Workshop.

Tjoanda, M. (2010). Wujud Ganti Rugi Menurut Kitab Undang-Undang Hukum Perdata, Jurnal Sasi Volume 16 Number 4 (Oktober-Desember 2010).

Utama, Meria. (2013). Lex Mercatoria sebagai Hukum yang dipilih Dalam Penyelesaian Sengketa Dagang Internasional, Fakultas Hukum Universitas Sriwijaya, 2013

\section{Thesis:}

Nurhadi, S.H. (2005). Enforcement of The International Arbitration Verdict (Pelaksanaan Putusan Arbitrase Internasional di Indonesia). Tesis Fakultas Hukum Universitas Airlangga,

\section{Legal Documents:}

International Centre for Settlement Investment Dispute (ICSID) Convention, yang telah diratifikasi oleh Pemerintah RI dengan diundangkannya Undang-Undang

218 Yustisia Volume 8 Number 2 (May-August 2019) $\quad$ Legal Protection Against The Failure ... 
Nomor 5 Tahun 1968 tentang Persetujuan Indonesia Atas Penyelesaian Sengketa Penanaman Modal Asing Antara Pemerintah Indonesia Dengan Investor Asing

Convention on the Recognition and Enforcement of Foreign Arbitral Awards (New York Convention 1958)

Law Number 25 of 2007 on The Capital Investment (State Gazette of The Republic of Indonesia Number 67 of 2007)

Law Number 30 of 1999 on The Alternative Dispute Settlements (State Gazette of The Republic of Indonesia Number 138 of 1999)

\section{Websites:}

Investopedia, Comparable Transaction, https://www.investopedia.com/terms/c/ comparable-transaction.asp\#ixzz4zKv6rxc9, dikutip pada 24 November 2017

Kevin Smith, The Law Of Compensation For Expropriated Companies And The Valuation Methods Used To Achieve That Compensation, Paper Law \& Valuation: Professor Palmiter, 2001, https://users.wfu.edu/palmitar/ Law\&Valuation/Papers/2001/Smith.htm pada 10 Januari 2017

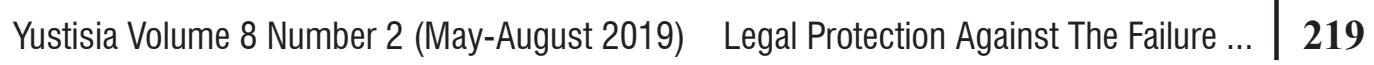

